\title{
PENGELOLAAN SURAT MASUK DAN SURAT KELUAR DI PERPUSTAKAAN STIPAP MEDAN
}

\author{
Nur'aini \\ Dosen Program Studi Perpustakaan dan Informasi Fakultas Ilmu Budaya \\ Universitas Sumatera Utara \\ Email : nuraini@usu.ac.id \\ Kerisman Halawa \\ Program Studi Ilmu Perpustakaan Fakultas Ekonomi Dan Ilmu Sosial \\ Universitas Sari Mutiara Indonesia \\ Email: kerisman16halawa@gmail.com
}

\begin{abstract}
Abstrak
Penelitian ini bertempat di Perpustakaan Sekolah Tinggi Pertanian Agrobisnis Perkebunan Medan. Tujuan penelitian ini adalah untuk mengetahui Pengelolaan Surat Masuk dan Surat Keluar dalam pemantapan dan penataan surat di Perpustakaan Sekolah Tinggi Pertanian dan Agrobisnis Perkebunan Medan. Pengelolaan Surat masuk dan surat keluar di perpustakaan STIPAP Medan dibagi menjadi dua adalah pengelolaan surat masuk meliputi unit petugas penghimpun atau penerima surat, penyortil, pencatat surat, pengarah surat, pengolahan surat dan penataan surat. Pengelolaan surat masuk diperpustakaan STIPAP Medan di laksanakan oleh Institusi STIPAP Medan. Sedangkan pengelolaan surat keluar meliputi pembuatan konsep surat, persetujuan konsep, mengetik surat sampai akhir, pemberian nomor surat, kop surat, penandatangan serta pencatatan surat. Pengelolaan surat keluar di perpustakaan STIPAP Medan dapat diterbitkan atau dikeluarkan oleh pihak perpustakaan dan diketahui oleh wakil ketua I sesuai dengan kebutuhan. Jadi, pengelolaan surat ini tidak sepenuhnya Perpustakaan mengelolahnya. Akan tetapi perpustakaan berfungsi untuk merekord file surat tersebut. Namun, tidak terlepas juga kerjasama antar pihak perpustakaan dengan Institusi STIPAP Medan dalam pengelolaan surat baik itu surat masuk dan surat keluar, sehingga memudahkan pencarian informasi terkait surat yang dibutuhkan oleh publik.
\end{abstract}

Kata Kunci: Pengelolaan surat masuk, pengelolaan surat keluar

\begin{abstract}
This research is located in the Medan Agricultural Agribusiness College Library. The purpose of this study was to determine the Management of Incoming and Outgoing Letters in stabilizing and structuring letters in the Library of Agriculture and Agribusiness in Medan Plantation. Management of incoming and outgoing letters in the Medan STIPAP library is divided into two is the management of incoming letters including the unit of collecting or receiving letters, sorters, note takers, letter directors, letter processing and letter structuring. Management of incoming mails in the Medan STIPAP library is carried out by the Medan STIPAP Institution. While the management of
\end{abstract}


outgoing letters includes drafting letters, conceptualisation, typing letters to the end, granting letter numbers, letter coping, signing and recording of letters. Management of outgoing letters in the Medan STIPAP library can be issued or issued by the library and is known by the vice chairman I as needed. So, the management of this letter is not entirely managed by the Library. However, the library functions to record the letter file. However, it is also inseparable from the collaboration between the library parties and the Medan STIPAP Institution with one another in managing letters both incoming and outgoing letters, making it easier to find information related to letters needed by the public

Keywords: Management of incoming mail, management of outgoing mail 


\section{PENDAHULUAN}

Dalam dunia perkantoran bentuk administrasi berupa berkas surat yang berguna bagi sebuah organisasi atau lembaga. Dapat dinyatakan bahwa surat itu merupakan barometer maju dan mundurnya sebuah perusahaan atau organisasi. Surat adalah alat komunikasi tertulis yang berasal dari suatu pihak dan ditujukkan kepada pihak lain untuk menyampaikan warta atau pesan berupa informasi, pemberitahuan, surat perintah, penawaran, peringatan, laporan dan lain sebagainya. Surat itu dapat disampaikan melalui secara langsung atau melalui pos. Surat sebagai suatu sarana komunikasi yang digunakan untuk menyampaikan informasi tertulis oleh suatu pihak kepada pihak lain. Dengan lebih jelasnya, Surat adalah alat komunikasi tertulis untuk menyampaikan pesan kepada pihak lain yang memiliki persyaratan khusus yaitu penggunaan kertas, penggunaan model/bentuk, penggunaan kode dan notasi, pemakaian bahasa yang khas serta pencantuman tanda tangan. (Agus Sugiarto, 2015:2).

Dalam Kamus Umum Bahasa Indonesia, menurut W.J.S Poerwadarminta pengertian surat adalah kertas yang bertuliskan atau alat untuk menyampaikan suatu maksud secara tertulis.Tertulis dalam hal ini adalah melalui secarik surat. Menurut Kamus Besar Bahasa Indonesia "surat" merupakan kertas dan sebagainya yang tertulis atau secarik kertas sebagai keterangan atas sesuatu yang tertulis. Mengapa pentingnya surat dibanding dengan melalui media secara langsung? Karena dalam dunia organisasi mengundang tamu yang terhormat itu harus melalui surat jika lewat kata -kata mungkin dipercaya atau tidak. Akan tetapi jika melalui surat maka terbukti jika itu benar atau tidak karena didalamnya tersirat cap dan tanda tangan pengirim surat.

Sebuah organisasi manapun tentu ada pengelolaan setiap devisi pekerjaan. Dalam dunia perpustakaan juga seperti begitu. Mengapa ada pengelolaan? Karena supaya lebih konsisten dan efektif dan efesien sehingga dapat mencapai tujuan yang di inginkan. Pengelolaan adalah sebuah rangkaian atau langkah langkah dalam mencapai suatu tujuan seperti adanya pengorganisasian. Oleh karena itu, dalam pengelolaan dibagi 
menjadi dua yaitu pengelolaan surat masuk dan surat keluar. Dari uraian diatas, penulis tertarik untuk mengetahui lebih lanjut tentang "Pengelolaan Surat Masuk Dan Surat Keluar Di Perpustakaan Stipap Medan”.

\section{KAJIAN PUSTAKA DAN HASIL PEMBAHASAN}

\section{A. Pengelolaan Surat Masuk}

Menurut Endang dkk (2009) "Surat masuk adalah surat-surat yang diterima oleh suatu organisasi/perusahaan yang berasal dari seseorang atau dari suatu organisasi. Pengelolaan surat masuk adalah semua kegiatan yang dilakukan sejak penerimaan surat masuk, pengelolahan/penyelesaian hingga surat tersebut tersimpan. Surat masuk diterima dari berbagai pihak baik dari instansi perguruan tinggi atau dari lembaga manapun. Pengelolaan surat masuk itu sebagai rangkaian kegiatan yang dilakukan dalam penanganan surat masuk dalam instansi/organisasi atau perpustakaan tersebut. Menurut Wursanto (1991) mengemukakan bahwa dalam mengelolah surat masuk terlebih dahulu perlu menetapkan organisasi pengelolaan surat masuk.

Dalam organisasi pengelolahan surat masuk di anataranya adalah:

a. Unit petugas penghimpun (penerima), Petugas penerima berfungsi :

- Menerima surat

- Menerima jumlah dan alamat surat

- Memberi paraf dan nama terang pada buku ekspedisi/lembar pengantar surat.

- Meneliti tanda-tanda kerahasiaan surat, kesesuaian isi surat serta keabsahaan surat.

- Meneruskan surat kepada penyortil.

Berdasarkan hasil wawancara dengan kepala Perpustakaan STIPAP Medan bahwa pengelolahan surat masuk itu diproses dan dikelola pertama melalui surat observasi. Surat observasi tersebut harus memerlukan persetujuan dari pihak perpustakaan dilanjutkan dengan pimpinan. Selama ada persetujuan dari pimpinan Pihak biro admibistrasi STIPAP maka surat izin observasi akan disampaikan pihak 
perpustakaan untuk bisa menerima bagi yang ingin melakukan observasi. Pihak perpustakaan membuat buku besar surat masuk, setelah itu surat masuk tersebut akan diarsip. Selama ini inventaris buku untuk surat masuk dikelola pada pihak rektorat, jadi perpustakaan STIPAP tidak membuat kembali inventaris tetapi hanya menerima lampiran surat dari pihak rektorat yang telah diproses. Jadi perpustakaan hanya menyimpan dan mengarsipkan surat yang telah disetujui dari biro administrasi. Selain itu ada juga surat masuk yang secara internal yang kita kelola, contohnya surat masuk departemen ISO. Pihak internal memberikan surat dan pihak perpustakaan menyusun file atau recordnya di tempat arsip, kemudian dilobangi dalam map surat, atau filing kabinet kemudian dibuat daftar recordnya yang ada dirak.

\section{b. Penyortil}

Setelah surat masuk telah diterima oleh pihak penghimpun surat maka surat tersebut dipisahkan berdasarkan alamat yang ditujui jiika surat itu untuk perseorangan atau untuk pimpinan. Perpustakaan STIPAP Medan saat telah menerima surat dan lampiran dari pihak institusi terkait surat masuk maka pihak perpustakaan menginformasikan kepada pengirim surat bahwa peneliti diperbolehkan izin observasi dengan surat balasan yang dibubuhi oleh kop surat STIPAP dan di tandatangani oleh pimpinan. Penyortil bertugas :

- Menerima surat masuk,

- mengelompokan surat kedalaman kelompok surat dinas atau surat pribadi,

- menyortil surat berdasarkan klarifikasi surat,

- membuka surat dinas berdasarkan jenis surat penting dan surat biasa; tidak boleh membuka surat rahasia atau surat pribadi,

- meneliti lampiran surat,

- membubuhkan tanda penerimaan pada setiap surat,

- menyampaikan surat yang telah terbuka atau tertutup kepada pencatat surat dengan melampirkan amplopnya. 


\section{c. Pencatat surat}

Pencatatan surat masuk di perpustakaan STIPAP Medan dilakukan oleh Pihak Institusi STIPAP. Pencatatan surat masuk ini dilakukan dengan menggunakan buku agenda. Petugas pencatat surat intitusi yang memproses apakah surat itu penting, rahasia atau biasa saja. Akan tetapi dengan catatan jika surat tersebut misalkan Surat penting yang diberikan kepada Pimpinan maka pihak Pencatat surat tidak diperbolehkan membuka surat itu kecuali jika pimpinan menginzinkan. Artinya yang mencatat surat masuk itu hanya Pihak Institusi STIPAP sedangkan perpustakaan tidak mencatat lagi. Pencatat surat berfungsi sebagai:

- Menerima dan menghitung dan mencatat surat yang sudah diteliti,

- mencatat surat tersebut pada pengantar surat,kartu kendali, lembar pengantar surat rahasia,

- menyampaikan surat diatas setelah dilampiri lembar pengantar, dan kartu kendali kepada pengarah.

\section{d. Pengarah surat}

Pengarah surat masuk diperpustakaan STIPAP Medan adalah menerima surat yang telah dilampiri surat pengantar atau kartu kendali dari pihak biro administrasi Institusi sedangkan surat lampiran atau dengan kata lain fotokopi kemudian pihak perpustakaan yang menyimpannya sedangkan aslinya dari institusi. Pengarah surat masuk berfungsi sebagai :

- Menerima meneliti surat yang telah dilampiri lembar pengantar atau kartu kendali, untu di arahkan dengan menunjukan siapa pengolah surat,

- menyampaikan surat diatas kepada pengolah surat melalui tata usaha,

- menyimpan arsip kartu kendali (1 lembar).

e. Pengelola surat

Pengelola surat masuk diperpustakaan STIPAP Medan dilakukan dengan menerima surat dari Institusi dan pihak perpustakaan juga menerima surat disposisi dari institusi hanya fotokopi aslinya dari institusi. 
Jadi pengelola surat masuk itu sebenarnya dilaksanakan oleh pihak Institusi sedangkan perpustakaan hanya menyimpan atau merecord beberapa file yang ingin di arsipkan diperpustakaan. Pengelola surat berfungsi sebagai berikut:

- Menerima surat dan membahas sendiri atau membahas dengan memberikan disposisi pada lembar disposisi yang tersedia,

- mengembalikan surat yang telah diolah kepada pengarah melalui petugas tata usaha yang ditempatkan padanya. Dalam pengembalian ini disertakan tindakan pengendalian surat dan lembar pengantar surat. Sedangkan jika surat rahasia hanya lembar pengantarnya saja yang dikembalikan.

\section{f. Penata surat}

Penataan surat masuk di perpustakaan STIPAP Medan adalah dilakukan oleh perpustakaan itu sendiri. Penataan surat masuk ini dilakukan ketika perpustakaan menerima surat dari institusi dan telah diolah institusi maka perpustakaan menyimpan surat tersebut dengan lemari berkas arsip surat masuk dan memberikan bukti kepada institusi bahwa surat tersebut telah disimpan oleh perpustakaan. Penataan surat berfungsi sebagai berikut:

- Menerima surat dari pengarah yang telah diolah untuk disimpan pada lemari berkas sesuai dengan sistem klasifikasi yang berlaku,

- menerima kartu kedali untuk disimpan pada tempatnya,

- mengirim kartu kendali lain kepada pengolah, sebagai bukti bahwa surat yang telah diolah sudah disimpan dibagian arsip. Namun, organisasi pengelolaan surat masuk diatas ketika kami observasi di perpustakaan STIPAP tidak sepenuhnya ada semua. Mengapa ? karena perpustakaan itu sebagai tempat penyimpanan koleksi bahan pustaka juga menyimpan arsip surat masuk dan surat keluar. Jika di Kampus perguruan tinggi tentu adanya struktur pengelolaan arsip kalau diperpustakaan tidak ada karena sumber daya manusia nya masih kurang 
memadai sehingga perpustakaan STIPAP dalam mengelola arsip tidak lagi tangani secara tupoksinya melainkan dilakukan dengan bersama-sama.

Perpustakaan STIPAP dalam mengelola surat tidak ada buku agenda atau buku ekspedisi. Mengapa karena perpustakaan itu hanya menyimpan atau menfilekan seluruh file yang ada di institusi. Salah satu contoh surat masuknya adalah surat observasi. Surat observasi adalah surat yang berasal dari perguruan lain ke perpustakaan STIPAP. Lalu yang mengangani surat observasi tersebut adalah pihak institusi. Pihak institusi nanti yang memberikan jadwal untuk kembali lagi observasi di Perpustakaan STIPAP jika ada surat balasan dari pihak kampus/perguruan tinggi. Jadi yang menangani itu semua adalah pihak institusi setelah pihak perpustakaan menyimpan surat tersebut kedalam kumpulan file.

\section{B. Pengelolaan Surat Keluar}

Surat keluar adalah surat-surat yang dikirimkan sebagai jawaban atau tanggapan atas isi surat masuk yang diterima dari organisasi, kantor, perusahaan, perguruan tinggi, agar terjalin hubungan timbal balik yang serasi dan berakibat menguntungkan kedua belah pihak. Sama halnya juga dengan pengelolaan surat masuk. Surat keluar juga dapat disebut sebagai surat yang dibuat dan dikirimkan kepada suatu instansi atau lembaga manapun yang berupa informasi penting yang ingin disampaikan.

Pengelolahan surat keluar dapat dilakukakn oleh Perpustakaan STIPAP Medan tanpa berpengaruh dengan Intitusi. Perpustakaan STIPAP Medan dapat mengeluarkan surat dengan ketentuan tertentu dimana yang mengetahui adalah Wakil ketua I dan ditanda tangani oleh kepala perpustakaan dan wakil ketua I bidang akademik dan kemahasiswaan, serta di bubuhi stempel dan nomor surat bisa nomor surat perpustakan dan juga bisa nomor surat wakil ketua I tergantu sesuai dengan kebutuhan. Pengelolahan surat keluar diperpustakaan STIPAP Medan sesuai dengan hasil wawancara dengan kepala perpustakaan bahwa pengelolahannya adalah jika kalau surat keluar, pertama sekali kita tahu bahwa sifat-sifat surat keluar bersifat surat pemberitahuan dan permohonan, contoh eksternal. Pihak departemen tidak boleh mengeluarkan surat. Misalkan perpustakaan 
mengajukan surat keluar ke BI Corner kan kepentingannya ke perpustakaan. Tapi, yang harus menandatangan harus Rektor atau pimpinan yang isinya tentang perpustakaan segala bentuk surat baik itu nomor surat cop surat harus dari institusi. Kita tidak ada disini perpustakaan STIPAP, seluruh Fakultas tidak boleh mengelurakan surat. Surat cukup satu kop surat adalah sekolah tinggi STIPAP. Walaupun isi nya tentang perpustakaan tetap Pimpinan kampus yang mengelolannya. Jika di STIPAP perpustakaan berada dibawah Wakil ketua 1 Bidang akademik jadi prosedur apapun katakana sifatnyya internal tapi tidak menggunakan cap STIPAP kalau internal yang ditandangi oleh kepala perpustakaan dan diketahui oleh wakil ketua 1, nomor surat bisa nomor surat perpustakaan atau nomor surat wakil ketua 1. Itulah prosedurnya.

Dari pendapat diatas dapat dipahami bahwa ada beberapa faktor yang membuat suatu surat menjadi surat keluar. Mungkin anda bertanya ada apa penyebabnya? Penyebabnya adalah untuk memenuhi panggilan surat yang telah diterima atau jawaban, sebagai wakil penerima surat, dan juga sebagai informasi berupa pemberitahuan. Namun surat menjadi surat keluar ada beberapa tahapan yang perlu di selesaikan harus mengikuti prosedur pembuatan surat keluar. Oleh karena itu, ada beberapa prosedur penangan surat keluar adalah sebagai berikut:

a. Pembuatan konsep surat

Berdasarkan hasil wawancara dengan kepala perpustakaan STIPAP Medan bahwa dalam sebuah organisasi atau perpustakaan misalnya mau mengajurkan pengadaan koleksi kepada wakil rektor II. Tentu saja terjadi proses pembuatan surat keluar. Lalu pembuatan surat pertama kali dibuat dulu konsep suratnya. Siapa yang membuat konsep surat? Tentu orang pengelola surat atau kepala perpustakaan atau pimpinan menyuruh admin terpecayannya atau bisa membuat konsep surat. Kecuali jika surat tersebut bersifat rahasia maka yang membuat konsep surat langsung pimpinan atau kepala perpustakaan misalnya dan langsung pimpinan yang mengetiknya. 
b. Persetujuan Konsep

Setelah admin atau tata usaha membuatkan konsep surat masuk maka pimpinan melihat dulu dan mengamati surat tersebut. Kemudian setelah surat tersebut benar maka pimpinan menyetujui konsep surat tersebut.

c. Mengetik surat sampai akhir

Setelah pimpinan atau kepala telah menyetujui konsep surat tersebut maka admin atau tata usaha menyerahkan kepada pencatat surat keluar. Dengan catatan tidak boleh mengurangi huruf atau kata dalam surat tersebut dan mengetikkannya hingga sampai akhir.

d. Penanda tangan

Setelah surat keluar telah selesai diketik oleh pencacat surat maka pencacat surat menyerahkan surat tersebut kepada pimpinan atau pejabat perpustakaan untuk dibubuhkan tanda tangan kemudian dikembalikan kepada tata usaha atau pencacat untuk dilampirkan kartu kendali.

e. Kemudian sebelum dikirimkan atau sebarkan kepada pihak lain suratnya, pihak pencacat surat perlu diberian nomor surat, cap surat dan lain yang berkaitan dengan ciri-ciri surat keluar.

f. Pencatatan

Maksudnya setelah surat asli dikirimkan kepada pihak lain maka kartu kendali lembar pertama diserahkan kepada unit pengarah, kemudian kartu lembar II dan III diserahkan kepada satuan kerja unit pengelolah dan kemudian unit pengelola kartu kendali II dan III ditandangangi sebagai alat bukti bahwa surat telah diproses dan dikirimkan ketempat tujuan dengan tidak ada halangan, kemudian diteruskan kepada penata arsip dan kartu kendali III dan konsep surat pertinggal di tinggalakan kepada pengelolah surat untuk di arsipkan ke filling cabinet. 
Sesuai dengan hasil wawancara dan observasi diperpustakaan STIPAP Medan bahwa pengelola surat masuk dan surat keluar dalam mengarsipkan surat ada beberapa tempat penyimpanan yaitu:

a. Folder (Map)

Folder (map) adalah semacam map tetapi tidak dengan daun penutup. Pada folder terdapat tab yaitu bagian yang menonjol pada sisi atas untuk menmpatkan titel file yang bersangkutan.

b. Guide (penujuk atau pemisah)

Guide (penujuk atau pemisah) adalah tempat berkas itu di simpan.

Sekaligus berfungsi pemisah antar berkas-berkas tersebut.

c. Berkas pengingat

d. Rak arsip

Rak arsip adalah rak untuk menyimpan berkas/arsip akan tetapi penyimpanannya tidak berbeda dengan penyimpanan buku di perpustakaan.

e. Filling cabinet

Filiing cabinet merupakan lemari arsip yang dipergunakan untuk menyimpan foleder yang telah berisi lemabaran-lembaran arsip bersama guidenya.

Perpustakaan STIPAP Medan adalah perpustakaan yang menyimpan berbagai arsip surat masuk dan keluar dari departemen dan sesuai dengan penguraian diatas bahwa pengelolahan surat masuk yang mengelola adalah institusi sedangkan surat keluar dapat dilakukan oleh perpustakaan tapi di ketahui oleh wakil ketua I. Jadi fungsi perpustakaan hanya merecord berbagai file kedalam tempat penyimpan. Penyimpanannya disimpan dalam Folder atau map dan untuk mengetahui arsip tersebut supaya mudah mencari maka perpustakaan membuat konsep atau kode seperti : kode surat masuk dan keluar di perpustakaan STIPAP Adalah A.1,A.2, A.3, A.4, A.5, A.6, A.7, A.8, A.9, A.10, A.11, kemudian arsip surat diperpustakaan STIPAP Medan penyimpanannya masih bersifat konvensional dan tidak di digitalisasi. 


\section{METODE PENELITIAN}

Metode penelitian yang digunakan adalah metode deskriptif dengan pendekatan kualitatif. Metode ini bertujuan untuk menjelaskan kejadian yang sebenarnya. Azwar (2004: 6) menyatakan bahwa "Penelitian deskriptif dilakukan dengan menganalisis hanya sampai tahap deskripsi, yaitu menganalisis dan menyajikan fakta secara sistematik sehingga dapat lebih mudah dipahami dan disimpulkan."

\section{IV.KESIMPULAN DAN SARAN}

\section{a. Kesimpulan}

Dari hasil pembahasan diatas mengenai pengelolaan surat masuk dan surat keluar di perpustakaan STIPAP Medan bahwa segala bentuk perarsipan dan pengelolaan ada yang bersifat internal dan eksternal. Jika dalam pengelolaan surat masuk yang menangani adalah institusi dan perpustakaan adalah tempat pengarsipan. Sedangkan pengelolaan surat keluar perpustakaan dapat mengeluarkan surat tetapi diketahui oleh wakil ketua I.

\section{b. Saran}

Perpustakaan juga sangat perlu dalam menyimpan dan pengarsipan berbagai surat baik itu masuk atau keluar. Mengapa?karena dalam akreditasi perpustakaan berpengaruh pada penilaian perpustakaan itu sendiri. Pengarsipan surat masih bersifat manual serta menggunakan kode perpustakaan sebagai pengingat dan temu kembali informasi arsip surat sebaiknya dalam pengelolaan surat telah menggunakan digitalisasi pengarsipan dan sumber daya manusia semakin bertambah dan berprofesional. 


\section{DAFTAR PUSTAKA}

Azwar. (2004). Metode Penelitian. Yogyakarta: Pustaka Belajar

Bathos. (2012). Manajemen Kearsipan : Untuk Lembaga Negara, Swasta dan Perguruan Tinggi.Jakarta: Bumi Aksara.

Selamat datang di web perpustakaan Sekolah Tinggi Ilmu Pertanian Agrobisnis Perkebunan.

https://library.stipap.ac.id/lib/

Sri Endang R., Sri Mulyani, Suyetty. (2009). Modul Melakukan Prosedur Administrasi. Jakarta: Erlangga.

Sugiarto, Agus dan Teguh Wahyono. (2015). Manajemen Kearsipan Modern (Dari Konvensonal ke Basis Komputer), ed. Baru. Jakarta : Gava Media

Poerwadarminta. (1976 ). Kamus Umum Bahasa Indonesia. Jakarta : Balai Pustaka.

Undang Undang Negara Republik Indonesia Nomor 43 Tahun 2009 tentang kearsipan.

Wursanto. (1991). Himpunan Peraturan Perundangan Tentang Kearsipan. Yogyakarta : Kanisius, 1991. 